\title{
Urban green areas in the days of urbanization: the case of Atatürk Forest Farm, Ankara, Turkey
}

\author{
E. Durusoy, D. Tuzcuoglu \& A. Akcabozan \\ Department of Architecture Faculty, Yildiz Technical University, Turkey
}

\begin{abstract}
Urban green areas, an important layer of urban nature, provide various environmental qualities as well as a number of social opportunities and aesthetic richness. They fulfil a number of functions in an urban context as a comprehensive tool for the long term protection of environmental sustainability through improving the quality of life. Hence, their successful conservation is crucial to achieving a sustainable level of urban development.

Atatürk Forest Farm (AFF), one of the biggest urban green areas of Ankara and the first urban farm of Turkey, was founded in 1937 for urban agricultural encouragement. AFF, as the private farm of Kemal Atatürk - the founder of the Turkish Republic, is also used as a laboratory to carry out experiments combining modern farming methods with industrial production. Indeed, AFF can be explained as an innovative green infrastructure for Ankara, the capital of Turkey. However, the speed of urbanization as well as current policies creates severe strains on AFF. Connected to these, the sustainable future of AFF is threatened by various construction activities, land privatizations, ownership divisions, etc.

At this point, by highlighting the benefits and challenges of urban green spaces, this paper explains the critical discussion of urbanization on greeneries with the help of the AFF case. The study will explore the importance of AFF with its planning history and location. It further investigates urban policies and of this unique green space of Ankara. Connected to the information gathered, the paper ends with a summary on urban green areas.
\end{abstract}

Keywords: urban green areas, transformation, sustainability, Atatürk Forest Farm (AFF). 


\section{Introduction}

Urban green areas that comprise public and private parks, forests, urban gardens, sport facilities, city orchards as well as fertile agricultural lands are significant components of sustainable cities. Urban green areas provide various environmental qualities by maintaining the balance of the natural urban environment. They are essential elements for urban quality such that the presence of urban green areas represents a fundamental role in the contemporary urban realm [1].

In addition to its environmental side, urban green areas also have economic, aesthetic, social and psychological benefits $[2,3]$. Thanks to a range of benefits in various forms and a variety of opportunities within cities which they have provided, urban green areas further fulfil a number of functions in an urban context as a comprehensive tool for the long term protection of environmental sustainability through improving the basic conditions of daily life.

There are also a number of values associated with urban green areas. These can be listed as "use value" which can be classified as direct use value - consumptive or non-consumptive; indirect use value - protection functions, mitigation and urban climate; option use value - future personal such as recreational use, bequest value - future generations' recreation or nature preservation values as well as cultural and historic values of urban forests and finally, existence value preserving urban biodiversity $[4,5]$. Therefore, urban green areas reinforce the identity of towns and cities, so provide attractiveness for a qualified living. In this context, they restore the environment, promote community and build relationships. Indeed, urban green areas improve the competitiveness of cities.

With regard to these features listed, successful conservation of urban green areas is crucial to achieving a sustainable level of urban development. However, in today's world, the speed of urbanization creates severe strains on urban greens such that the current trends unfortunately suggest an increasing degradation through existing urban green areas. Hence, there is increasing concern on how to protect environmental sustainability against the speed of urbanization.

At this point, the purpose of this paper is to emphasize the importance of the conservation of urban green areas for sustainable cities by investigating Atatürk Forest Farm (AFF) - Atatürk Orman Çiftliği (AOÇ). The study will present AFF as one of the most significant and innovative urban green areas that is threatened by different forces. In doing this, the paper investigates the history, development process as well as the progression of urban transformation of AFF in the course of time. It further puts forward a discussion on AFF and urban green areas in order to develop a number of suggestions. The paper concludes with a summary on urban green areas that combine all the information given for a city to become sustainable in the days of urbanization. 


\section{A brief history of Atatürk Forest Farm}

\subsection{Formation and development}

Being one of the biggest urban green areas of Ankara and the first urban farm of Turkey, AFF was founded in 1937 for urban agricultural encouragement of the capital. Nonetheless, it can be said that the first steps of AFF were taken in the mid-1920s by Mustafa Kemal Atatürk, founder of the Turkish Republic. On May 5 of 1925, Atatürk bought 2000 hectares land from Mrs Faika, the wife of Abidin Pasha [6-10]. Located along the skirts of the city, these 2000 hectares of land then extended through Balgat, Etimesgut, Cakırlar, Macun, Güvercinlik, Tahar, Yagmur and Baba districts [6-9]. A number of agricultural lands and green areas were also included into the holistic configuration of AFF in the course of time [11, 12]. Thereby, the initial boundaries of AFF were broadened and reached 5200 hectares, which is indeed an appropriate size for a modern urban green enterprise including gardens, museums, zoo, picnic fields, forests, etc. [8-10].

AFF was not only an association aimed to make profit, but also an innovative green infrastructure for its close setting in micro and for the capital in macro scale (figs 1 and 2). The main idea behind composing that kind of urban green area within the heart of the capital was closely related with the ideology behind the philosophy of 'Republic' [7, 9, 10]. It was directly managed by Atatürk until 1937 $[9,10]$. Like all his other assets, Atatürk donated the farm to the Republic of Turkey Treasury with two testament letters written in 1937 [9]. During that time interval, when AFF reached its largest borders, "Government Agricultural Management Association" was established to manage the farm with a law that came into force in 1938 [9]. Following this progress, AFF, named "Forest Farm" and "Ghazi Forest Farm" in the past has taken its current name - "Atatürk Forest Farm" with the law numbered 5659 entered into force in 1950 [13, 14]. Then, it became a corporate identity public association that is adhered to the "Ministry of Agriculture and Rural Affairs" [13, 14].

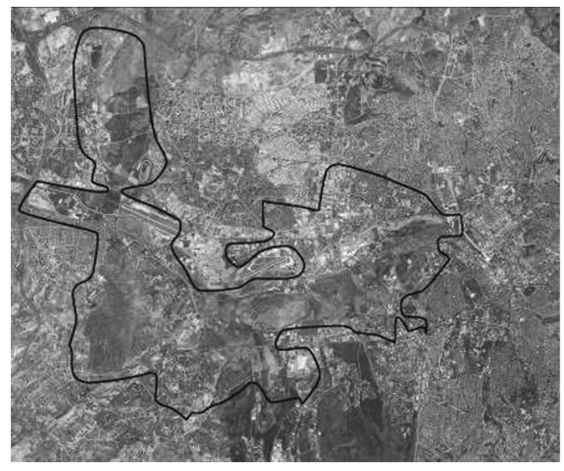

Figure 1: 1938 dated Google Earth rendering showing the largest borders of AFF (rendering prepared by the authors). 


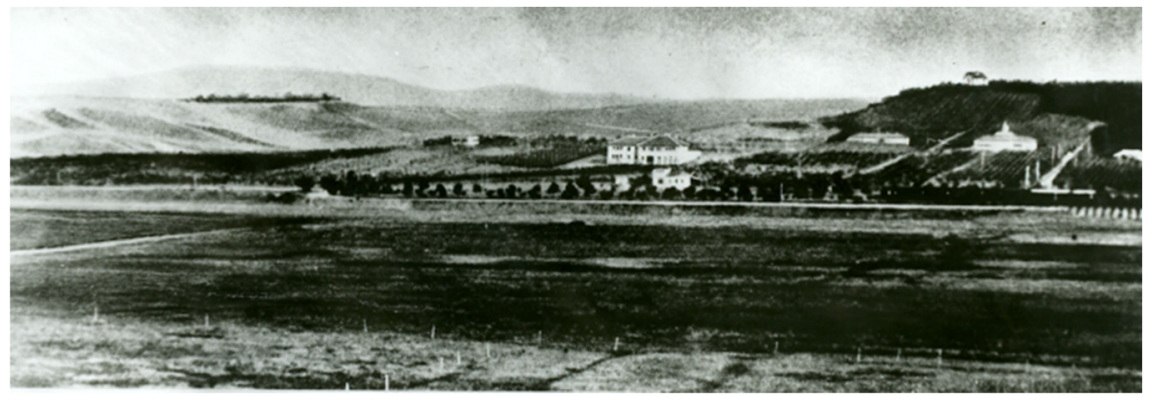

Figure 2: General view of the special landscape of AFF, 1939 [15-Inventory number: 169].

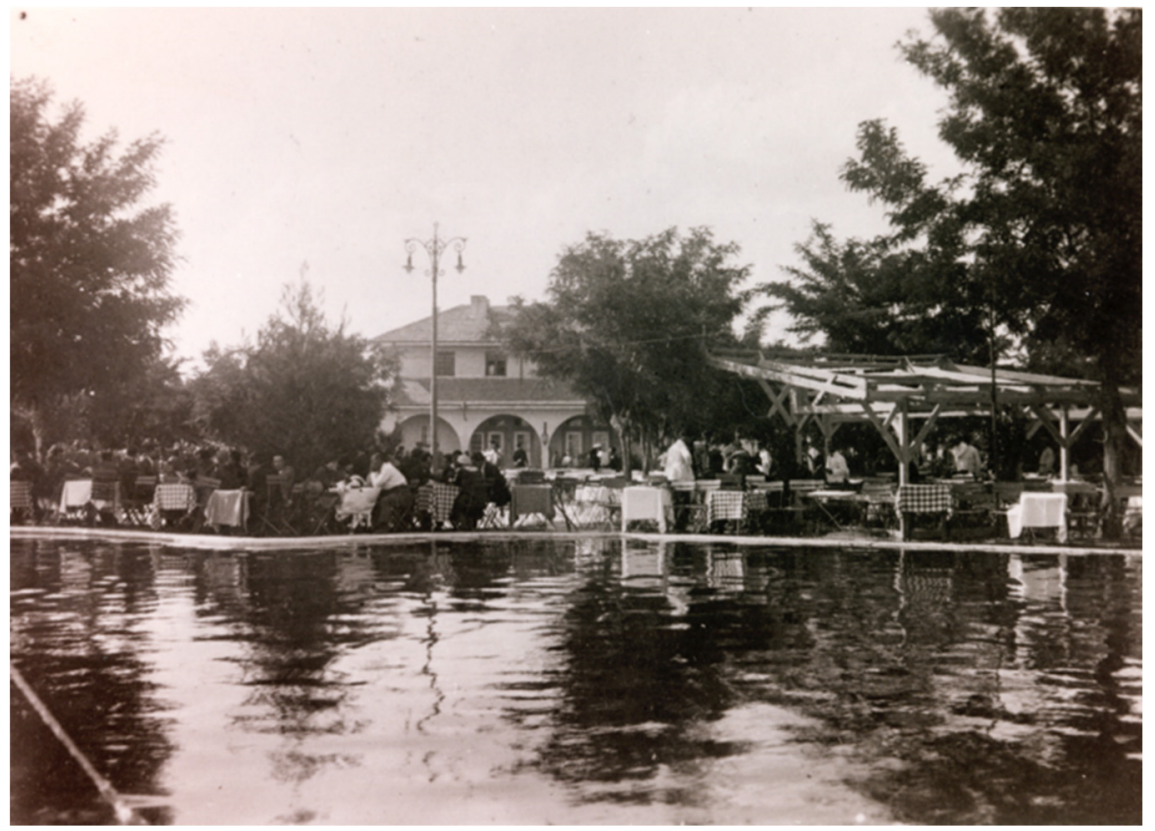

Figure 3: Marmara Pool and social life of AFF [15-Inventory number: 1648].

In depth, AFF was mainly established to create areas where people living in Ankara can rest and enjoy (fig. 3). It also helped farmers who need seed and stud as well as to foster them by buying the harvests produced within AFF with deserved values rather than market standards [8]. With this kind of method, AFF directly assisted the production and sale of local, clean and economical products especially milk, cheese, yoghurt, grain, wine, beer and various vegetables [10]. There are also special units for producing leather, mineral water and iron [9]. Thereby, people living in Ankara have the chance to obtain and consume fresh and healthy foods, goods and nourishment. AFF further supported various experiments combining modern farming methods with industrial production as well as hosted 
different types of animals and presented them in an entertaining and educational way to the society $[8,10]$. In this way, it has set a modern model to the villagers and a recreational gathering area for the people of Ankara.

Related with its principal purpose of establishment; agriculture and environmental knowledge as well as animal husbandry were prior stages realized $[9,10]$. Afterwards, a number of small-scaled industrial factories were established as extensions of those local productions. In order to ensure the pattern of manufacture, to benefit the economy and to evaluate the relationship with the market; a group of commercial structures were established correspondingly [10]. The above-mentioned industrial and commercial structures were also supported with markets and restaurants [16]. In addition, an amusement park, a beach and various outdoor coffee places were constructed within AFF in the course of time [9]. Later, a special type of store that only sells foods, artefacts and goods produced in this green area namely "AFF Stores" was established. It is also known that AFF has been subject of poetries, novels and stories of the past $[10,14]$. There are also a number of paintings depicting this special urban green area. Thanks to these features emphasized and facilities operated, AFF has also closed the gap of social and cultural lifestyle for the inhabitants of the capital.

There are also a number of registered historical structures with various functions within the boundaries of this urban green area. Thanks to their special qualities dating back to Republican times, most of them have presented "historical documentary", "aesthetic", "educational", "functional" and "memory" values. As a crucial example of the First National Architecture Movement, one of these significant structures is "Ghazi Train Station" designed by Ahmet Burhanettin. This structure, dating back to 1926 is now serving as a restaurant [17]. "Marmara Kiosk", "Beer Factory", "Beer Factory Turkish Bath", "AFF Bridge", "TCDD Apartment House", "MKE Cartridge Factory", "Ataturk's Sogutozu House" and "Onuncu Yll Primary School" should also be specified as important old registered structures located within the borders of AFF [10, 14] (fig. 4). There are also a group of residential structures for workers showing modern details built in 1937 $[10,17]$. Although it no longer exists, AFF also hosted the first and biggest modern zoo designed by Necdet Pence in 1933 [8]. All of these structures dating back to Republican history exemplify the modern architectural heritage of Ankara.

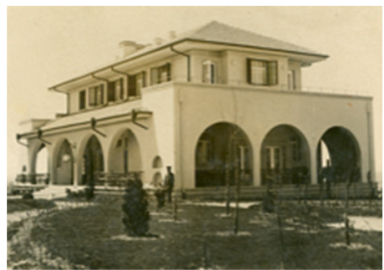

(a)

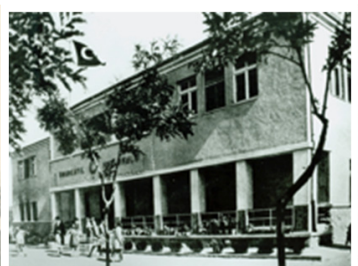

(b)

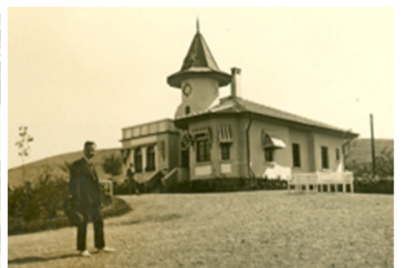

(c)

Figure 4: (a) Marmara Kiosk constructed in 1928, (b) Onuncu Y1l Primary School constructed in 1933 and (c) Ghazi Kiosk constructed in 1925. [15-Inventory numbers: 1130, ACF0412 and 761; respectively]. 
A number of dwellings were also built on this specific site. Most important among them are a house dating back to 1937 for Ülkü Adatepe - adopted daughter of Atatürk and a villa for the head of AFF designed by the famous Australian architect Ernst A. Egli between 1936 and 1937 [17]. Another residential structure that should be underlined is a replica in which Atatürk born in Thessaloniki, was opened to visitors in 1981 with the name of "Atatürk Forest Farm Atatürk House Museum" [14].

AFF was neither designed nor developed in accordance with a specific plan. In order to end this organic pattern of the farm, a basic plan layout of AFF was drawn by Egli [17]. Egli's 1/5000 scaled sketch dating back to 1934 proposed a centre at Ghazi Train Station and a main axis connecting all the sections of the farm in a holistic manner. Two years after the plan of Egli, Hermann Jansen who is one of the famous planners of Ankara was assigned for the planning task of AFF. Likewise, Egli, Jansen also prepared a comprehensive plan for this specific site by proposing recreational areas, educational facilities and wide gardens [17]. Despite some deteriorated parts, the collective effort of Egli and Jansen, two well-known architects and city planners of the era, mainly formed the development of AFF.

With regard to the above mentioned valuable physical outline, social configuration, economic structure as well as cultural accumulation; AFF has become a part of the collective memory of the Turkish nation and a crucial subject of sustainable conservation of Ankara in the course of time. Thanks to this point of view, AFF was declared as a natural and historical protected site with the 2436 number committee decision taken by the Conservation Board of Cultural and Natural Assets in 2nd June 1992 [18]. Then in 1993, the Board determined the borders of site and declared this special landscape as a 1st Degree Site Area in 1998 [18].

\subsection{Transformation and urbanization}

Experienced in most of the urban green areas, AFF has also been negatively affected by recent urban and/or transformation policies. Although this special landscape has always played a distinctive role in terms of numerous perspectives, AFF has unfortunately been subject to inappropriate or fragmented plans, resolutions and/or orders developed mostly by governmental authorities for legal, administrative, economic and/or political purposes over the last twenty years.

Starting from the beginning of the 1950s, the fundamental basis of AFF has started to be weakened. This transformation was initiated with a rental process. When the donation of AFF was given to the Republic of Turkey Treasury until the end of 1950s, 737.2 hectares of 5200 of AFF was rented to various governmental organizations [18]. Afterwards, the unique landscape of AFF continued to be broken down into small and interrelated segments. Those individual pieces were given functions such as housing, commerce, tourism, sports, industry etc. This breakage can be underlined as the first and foremost intervention that has threatened the holistic structure and sustainability of AFF.

Between 1950 and 1983, various laws were enacted [18]. Connected to some of these major laws (shown in Table 1), division of AFF continued. Thereby, a significant section of this special green area was sold to diverse institutions or 
transformed by privatization (fig. 5). At the end of this interval, the surface area of AFF was reduced to 300 hectares. Especially, the pieces of AFF that were allocated or sold to the Machinery and Chemical Industry Institution, cement factories, coal depots, transformers, factories, sports facilities, housing cooperatives, universities, Ankaray, storage facilities, Ankara Intercity Bus Terminal, Turkish Army house, tourist resorts etc. have changed the initial appearance of AFF [18].

Table 1: $\quad$ Major laws on transformation of AFF [18].

\begin{tabular}{|l|l|}
\hline Date & Description \\
\hline 1954 & -Sale of 807 hectares of AFF with 6238 numbered Law \\
\hline 1957 & -Sale of 114.8 hectares of the AFF with 6947 numbered Law \\
\hline 1959 & $\begin{array}{l}\text {-Sale of } 72.5 \text { hectares of AFF and implementation of assignment of some } \\
\text { area previously exchanged to the related persons with 7310 numbered Law }\end{array}$ \\
\hline 1976 & $\begin{array}{l}\text {-Sale of } 16.7 \text { hectares five hundred metre square part of AFF to Ankara } \\
\text { Municipality with } 2015 \text { numbered Law }\end{array}$ \\
\hline 1981 & $\begin{array}{l}\text {-Sale of } 53.6 \text { hectares of AFF } \\
\text {-Development of the State Cemetery with } 2549 \text { numbered Law }\end{array}$ \\
\hline 1983 & -Sale of 183.8 hectares of AFF with 2823 numbered Law \\
\hline
\end{tabular}

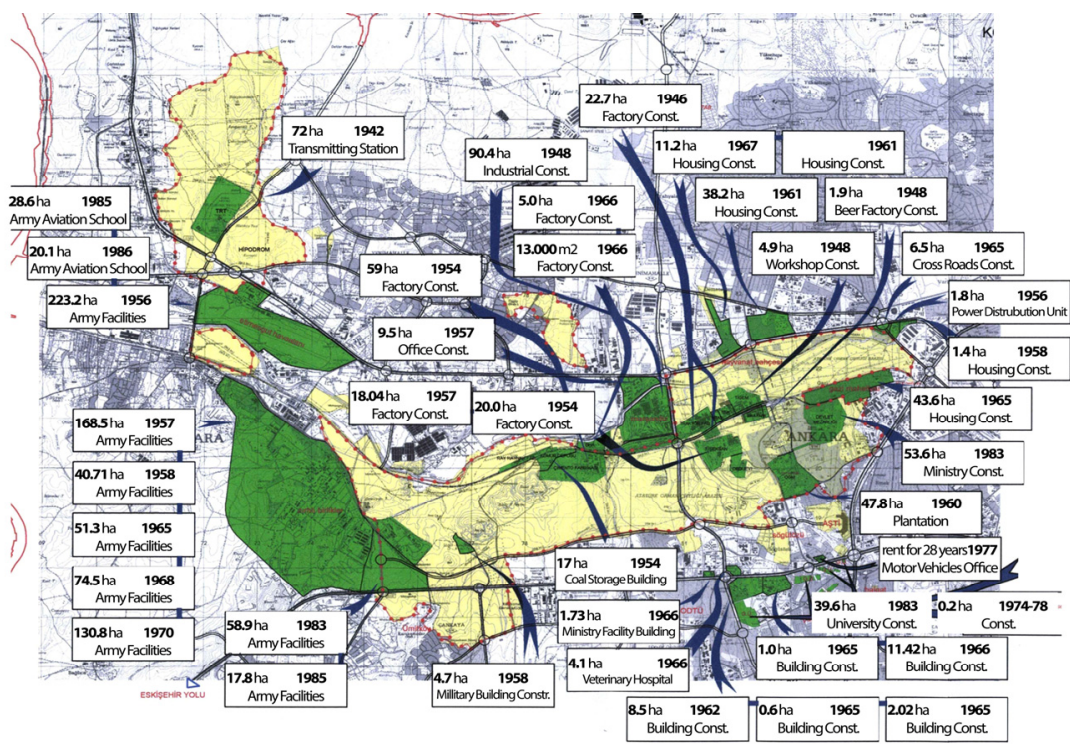

Figure 5: Fragmentation of AFF as a result of the laws enacted between 1953 and 1986 (rendering revised and prepared by the authors) [18].

During these years, not only AFF but also Ankara experienced significant changes due to rapid urbanization. In order to avoid suffering negative consequences, an international competition was announced in the 1950s to develop a macro plan layout for Ankara [9]. It is noteworthy that rather than the 
vibrant urban green area proposed by Egli and Jansen, the winner project of the competition, Yucel and Uybadin Plan, identified the fertile landscape of AFF as an uncultivated section [20]. Furthermore, the awareness of the increasing air pollution around Ankara revealed during the 1970s that showed the importance of green areas to society were not adequate enough to preserve the authentic function of AFF in the forthcoming years. Even the declaration of AFF as a natural and historical site by the Conservation Board of Cultural and Natural Assets and 1st Degree Site Area in 1998 did not contribute in increasing the consciousness regarding this unique landscape. Hence, transformation and urbanization of AFF has continued since 2006. This process is summarized in Table 2 .

Table 2: $\quad$ Major laws on the transformation and urbanization of AFF [18].

\begin{tabular}{|l|l|}
\hline Date & Description \\
\hline 2006 & -Authorization of plan arrangement for AFF was transmitted to Ankara \\
& $\begin{array}{l}\text { Metropolitan Municipality with the 5524 numbered "Law for Amending } \\
\text { Foundational Law of Atatürk Forest Farm" }\end{array}$ \\
\hline 2010 & $-1 / 10000$ scaled AFF Areas Master Development Plan was realized \\
& -Master Development Plan for Conservation Purposes for 1st Degree \\
& $\begin{array}{l}\text { Natural and Historical Site Area was enacted } \\
-1 / 10000 \text { scaled Transportation Schedule and 1/10000 scaled } \\
\text { Transportation Application Projects were prepared by Ankara Metropolitan } \\
\text { Municipality }\end{array}$ \\
\hline 2011 & $\begin{array}{l}\text {-AFF Facilities Area was transformed from 1st to 3rd Degree Natural Site } \\
\text { Area }\end{array}$ \\
\hline 2012 & $\begin{array}{l}-7 \text { hectares of the 1st Degree Natural and Historical Site Area of AFF was } \\
\text { declared as 3rd Degree Natural Site Area } \\
\text {-Prime Ministry Service Building was started to be constructed within this } \\
\text { section } \\
-37,6 \text { hectares of AFF were decided to be revaluated as "Atatürk Forest } \\
\text { Farm Zoo Renovation Area" that comprise an amusement park known as } \\
\text { "AnkaPark" } \\
\text {-A number of principal roads were constructed within the borders of AFF }\end{array}$ \\
\hline
\end{tabular}

To sum up, not only the physical but also the social and economic structure of AFF have started to witness diverse changes from macro to micro scales. Slow process of legal procedure also helped those changes to be implemented. Connected to the inconvenient transformations; the above-mentioned construction activities, land privatizations and ownership divisions that all have threatened the sustainable future of AFF converted the general layout of AFF by threatening its holistic appearance and sustainable configuration.

\section{Discussion}

AFF, located within the core of Ankara, can be respected as one of the special urban greeneries. As the only lungs of the capital, the preliminary formation of AFF is a project of modernity $[7,10,17]$. AFF encouraged urban agriculture as a public laboratory not only to increase economic efficiency, but also to support cultural togetherness. It has represented civilization, enlightenment, development 
and production. Moreover, the development process of this valuable land changed the identity of Ankara by making the capital more glamorous since its establishment $[10,22]$. Thanks to its planned layout, historically valuable structures, registered buildings, productive areas and different uses are located within its borders. With regard to these environmental, physical, economic, social and cultural values; AFF has the potential to accomplish sustainability of Ankara.

Nonetheless, the physical fabric of AFF has been gradually devalued parallel to the rapid urbanization (fig. 6). As may have been expected, the negative effects of urbanization have destructively affected the general setting of AFF presenting environmental values, architectural features as well as the community life of Ankara. During this time interval, improper, out of context, new structures have built, distinctive structures of modern movement have started to be reused with improper functions, spaces formerly used by pedestrians have been occupied by motor vehicles, etc. AFF has lost nearly a half of its lands and valuable buildings by selling, transferring or renting them to other institutions or people. Therefore, historical values have disappeared, existing orders have diversified, open areas have been exposed to physical units as well as physical and social accessibility of the public to AFF have been restricted.

Connected to these recent alterations changing its landed property for other purposes than the goals set at the beginning, the authentic role of AFF has been distorted. Thereby, the transformation coming parallel to the experienced urbanization has disturbed the enduring identity of AFF from this time on, such that the future of AFF has aroused attention and become one of the most controversial topics for the public.

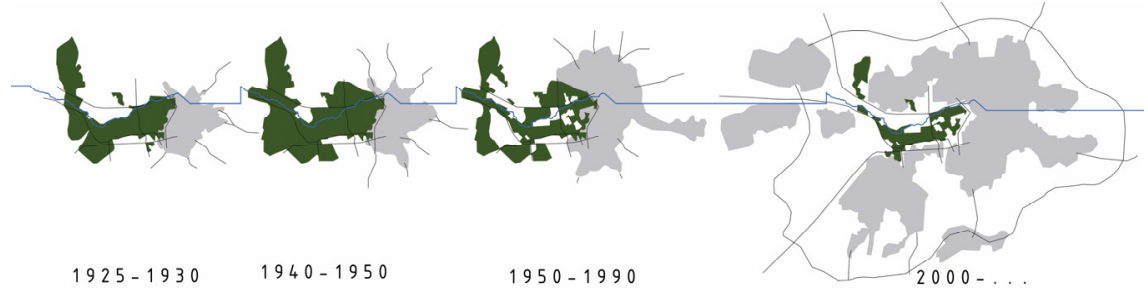

Figure 6: Urbanization of AFF (rendering prepared by the authors).

AFF, losing its special meaning by fragmentation, should not be left to its fate. Rather, it should reflect the bright sides behind the idea of 'Republic', the approach of a modern capital and the philosophy of Atatürk. Having almost the same age as the Republic, it should be respected not only as a green area for ecological, recreational, economic and functional values; but also as a symbol expressing a combination of historical, aesthetic, educational and functional values. Hence, it can be regarded as a special product of the modern world and contemporary civilization, as it was at its formation period. Since AFF reflects the "combined works of nature and humankind by expressing a long and intimate relationship between peoples and their natural environment", it may also be evaluated as a subheading under the "cultural landscapes" criteria of UNESCO [23]. With regard to all of these inputs, the successful conservation of AFF together with its long- 
lasting signs is crucial to achieving a viable level of urban development for the sustainable future of Ankara.

It is still possible to refer to potentials for AFF. In order to show the potentials behind this unique urban green area located within the core of the capital, competitions that helped to accumulate information and collect viewpoints of different participants should be encouraged. For this purpose, city management and urban scholars should work together, and develop proposals relevant to the aforementioned aims. By combining tangible and intangible contexts in city scale with long-term policies, a functioning communication network between these stakeholders, such as universities, municipalities, nongovernmental organizations especially the Chamber of Architects and Chamber of City Planners should be set.

These macro scale efforts should be supported with micro scale proposals. In a detailed manner, the accessibility of AFF should be increased. Civic participation should be arranged in particular sections, continual and collective production patterns should be sustained for cultural, economic and social achievement; so that people can embrace AFF. To add, these opportunities which all aim to increase society awareness and encourage people to vitalize the site should be prolonged.

\section{Conclusion}

The main aim of this paper has been to place on the perspective and management of urban green areas through the case of AFF. Providing a number of environmental and physical qualities as well as various social opportunities, economic gatherings and aesthetic richness; urban green areas are important layers of cities.

In conclusion, it can easily be said that urban green areas have the potential to promote economic diversity, ecological variability, societal relations and psychological wellbeing of cities and societies. Therefore, urban green areas should holistically be conserved, sustained and developed in a sensible manner with their historical contexts, physical infrastructures and social networks through the proper use of urban planning, conservation and architecture approaches. Only in this way, can they contribute to the sustainability of cities by sustaining their ecological, social, aesthetic, economic and psychological benefits for cities to become sustainable.

\section{References}

[1] Cameron, R.W.F., Blanusa, T., Taylor, J.E., Salisbury, A., Halstead, A.J., Henricot, B. \& Thompson, K., The Domestic Garden - Its Contribution to Urban Green Infrastructure. Urban For. Urban Green. (11), pp. 129-137, 2012.

[2] Shah Md. A. H., Urban Green Spaces and an Integrative Approach to Sustainable Environment. Journal of Environmental Protection, pp. 601608, 2011.

[3] van Leeuwen, E., Nijkamp, P. \& Noronha V. T., The Multi-Functional Use of Urban Green Space, International Journal of Agricultural Sustainability, (8), 1\&2, pp. 20-25, 2010. 
[4] Tyrväinen L. Monetary Valuation of Urban Forest Amenities in Finland. Academic Dissertation. Finnish Forest Research Institute, Research papers 739. Finnish Forest Research Institute, Vantaa, 1999.

[5] Turner K., Pearce D. \& Bateman I., Environmental Economics: An Elementary Introduction. Harvester, Wheatsheaf, 1994.

[6] Atatürk Forest Farm, An Evaluation on 5524 Numbered Law and Conservation Development Plan, online. http://www.mimarlarodasi ankara.org/index.php?Did=2652

[7] Kimyon, D. \& Serter, G., Atatürk Orman Çiftliği'nin ve Ankara'nın Değişimi Dönüşümü, Planlama Dergisi, 25(1), pp. 44-63, 2015.

[8] Ozdemir, G. \& Mustafa, Ç., Ataturk Forest Farm's Management and its Relationship with the Cooperatives, African Journal of Agricultural Research, 7(8), pp. 1238-1244, 2012.

[9] Atak, E. \& Sahin, Z. S., Atatürk Orman Çiftliği’nin 79 Yılı ve Çiftliğin Korunmasına Yönelik Politika Arayışları, Planlama, (3), pp. 80-88, 2004.

[10] Kaçar, D., Kültür/Mekan: Gazi Orman Çiftliği, Ankara. Koç Üniversitesi VEKAM Yayınları Araştırma Dizisi III, Yayın No: 36, Ankara, 2015.

[11] Anonymous. The General Administration of Atatürk Forest Farm, İstanbul, 1953.

[12] Gürocak. Atatürk Forests, Atatürk and Agriculture, Ankara University, Agricultural Faculty Publications, Ankara. p. 176, 1981.

[13] 5659 Numbered Ataturk Forest Farm Directorate Law, online. http://www.mevzuat.gov.tr/MevzuatMetin/1.3.5659.pdf

[14] ODTÜ Mimarlık Fakültesi AOÇ Araştırmaları, http://aocarastirmalari.arch. metu.edu.tr/

[15] Koç University-VEKAM Archive. Inventory numbers: 169, 761, 1130, 1648 and ACF0412.

[16] Devlet Çiftliğinden Rant Odağına: Atatürk Orman Çiftliği, http://haber.sol. org.tr/kent-gundemleri/devlet-ciftliginden-rant-odagina-ataturk-ormanciftligi-haberi-48135

[17] Alpagut, L., Atatürk Orman Çiftliği’nde Ernst Egli’nin İzleri: Planlama, Bira Fabrikası, Konutlar ve "Geleneksel” Bir Hamam, ODTÜ Mimarlık Fakültesi Dergisi, (27-2), pp. 239-264, 2010.

[18] Union of Turkish Architects, Don't Legitimate The Lawlessness In Atatürk, Ankara Branch, Ankara, 2014.

[19] Ankara Metropolitan Municipality, http://www.ankara.bel.tr/en

[20] https://www.ankara.bel.tr/files/3113/4726/6297/3-makroform.pdf

[21] ProjeFikir, Kent Düşleri 9: Atatürk Orman Çiftliği Alanları Uluslararası Proje Fikir Yarışması, Online. http://www.mimarlarodasiankara.org/aoc/

[22] Atatürk Orman Çiftliği, http://www.aoc.gov.tr/

[23] Mitchell, N., Rössler, M. \& Tricaud, P., World Heritage Cultural Landscapes: A Handbook for Conservation and Management, UNESCO World Heritage Papers - 26, online. http://whc.unesco.org/documents/ publi_wh_papers_26_en.pdf 